\title{
Four-Way Linkages of Trade Openness, Income Inequality, Environmental Degradation and Economic Growth in Malaysia
}

\author{
Navanita Rajasegar ${ }^{1}$, Rossazana Ab-Rahim²*
}

\author{
${ }^{1,2}$ Faculty of Economics and Business, University Malaysia Sarawak, 94300, Kota Samarahan, Sarawak, Malaysia \\ ${ }^{*}$ Corresponding author. Email: arrossazana@unimas.my
}

\begin{abstract}
The linkages between trade openness, income inequality, environmental degradation, and economic development has sparked much discussion in the economics literature. Despite the fact that studies on these variables have been done, no studies have been conducted explicitly analysing the linkages of these four variables. Hence, this study aims to investigate the four-way linkages of trade openness, income inequality, environmental degradation and economic growth in Malaysia. The variables utilised in this study are trade openness, income inequality, environmental degradation and economic growth for a period of 30 years (1990-2019). The data used in this study was obtained from World bank, the Global Economy and Department of Statistics, Malaysia. The general objective of this study is to investigate the relationship between trade openness and economic growth in Malaysia. The methodologies employed in this study are Unit Root test which compromises of Augmented Dickey-Fuller and Phillips-Perron Test to test for stationarity, while Johansen and Jeselius test is used to test whether the variables are cointegrated, Vector Error Correction Model test to analyse the long run relationship of the variables by the values of Error Correction Term(ECT), Granger Causality test to analyse the short run causalities between these four variable, and diagnostic tests which consists of Normality test, Serial Correlation LM test, Heteroskedasticity test, Ramsey RESET test, CUSUM and CUSUM of Squares test. The results of this study show that long run and short run causalities exists between these variables. It shows that trade openness and environmental degradation have positive impacts whereas income inequality has negative impacts on the economic growth in Malaysia. The creation of energy-saving strategies is anticipated to contribute to reduced CO2 emissions which would reduce the income inequality while maintaining the GDP growth and trade openness, and the study findings offer Malaysian and other decision- makers important policy insights in a number of ways. So, in order to achieve sustainable development, Malaysia's policymakers will need to implement a balanced plan that stimulates growth, closing the gap of incomes and international trade.
\end{abstract}

Keywords: gross domestic product (GDP), trade openness, income inequality, environmental degradation

\section{INTRODUCTION}

The manufacturing sector has grown substantially over the past few years, contributing to an increased Gross Domestic Product (GDP) and as of 2019, the service sector has been the largest contributing sector which contributes about $57.3 \%$ of the country's GDP respectively. (Department of Statistics Malaysia, 2021). Malaysia's GDP reduced by $0.5 \%$ in the first quarter of 2021, sustaining its resurgence from a $3.4 \%$ loss in the previous quarter, according to the Gross Domestic Product First Quarter 2021 report. The development of the industrial sector and the recovery of the agriculture sector aided the economy's recovery. According to Malaysia's Trade Statistics (MATRADE), international trade is one of the main contributors to Malaysia's prosperity in terms of economic growth. Singapore, China, the US and Japan are Malaysia's major export and import allies.

During the 1980s, the barriers to trade and investment in Malaysia have decreased as compared to other regions except for Singapore and Hong Kong due to world trade policies have moved from import substitution to export promotion strategies. As a result, Malaysia was able to respond positively to the expanded prospects of global trade growth. Malaysia has developed into one of the major trading nations in the world. Malaysia has been a party of GATT since the year 1957, and is also the founder member of the World Trade Organization (WTO). Malaysia has exhibited a keen commitment to develop regional and bilateral trade links through the agreements done with regional groups and nations. Malaysia's trade strategy has been to aim for a more liberalized and fairer global trading environment whilst maintaining multilateral trading structures focused on WTO laws as a top priority.

Malaysia's economic growth has had important effects on the distribution of income and on poverty. While the poverty rate has declined, the distribution of wealth still shows a pattern that is not healthy. Official estimates indicate the poverty rate in Malaysia has been gradually decreasing but the wealth distribution reflects the pattern of fluctuation. The scatter diagram in Figure 1 shows the GDP growth and the poverty rate in Malaysia. However, the United Nations (UN) contradicted Malaysia's 2019 poverty projections. 
Malaysia stated that poverty had decreased to $0.4 \%$ in 2016 from $49 \%$ in 1970 . This is because poverty in Malaysia is defined as a monthly family income of less than RM 980. Nevertheless, in 2019, United Nations experts claimed that Malaysia had set the poverty level too low, and thus a household earning more than RM 980 and less than RM 2000 was still classified as poor, in other words, currently still in the poverty group.

In order to ensure that the trends, desires and dynamics of Malaysian households are in line with the changes that have been made since 2018, the Government has revised its estimation criteria for Poverty Line Income (PGK). PGK technique was last revised in 2005 . The poverty rate for 2019 was 5.6\% (405,441 households) based on this new PGK. In 2016, the poverty rate was estimated based on PGK 2005, at a rate of $0.4 \%$ (24,700 houses). This means that the country's poverty rate dropped by two percentage points as calculated using the latest PGK metric from 7.6\% in 2016 to $5.6 \%$ in 2019 .

In terms of environmental deterioration, the impact of emission of greenhouse gases on the quality of life has grown in recent years. One of the major causes behind this phenomenon is thought to be growing economic expansion and the resulting degradation of the ecology. Because of these nations' industrial systems, the relationship between economic activity and environmental destruction may be more environmentally damaging in developed countries. The loss and deterioration of natural resources, environmental pollution, and consequent social and economic consequences are a widespread issue specific to developed nations. Therefore, environmental concerns are a primary area of focus for politicians and policymakers in these countries while forming strategic decisions on human growth and economic wellbeing.

\subsection{Problem Statement}

This study is different compared to what other researchers have done in the sense that there is a gap in the literature because a study involving the linkage of all these said variables mentioned have not been done hence, this is the first study done involving all these variables together to analyze the linkage. So, the current study focuses on the linkage between these variables using time series analysis focusing only on one country, Malaysia.

Understanding the rise of GDP might have a major impact on the economy has been very important for policymakers. There is a stream studies undertaken by scholars to investigate this problem. In this study, the relationship between the dependent variables and the independent variables are tested to know the significance of these variables on the economic growth. The progress of the development of the developing nations is seen by rapid economic growth. The planning process has been seen as struggling to boost the well-being of the nation, in the absence of economic growth. Consequently, it is predicted that urban construction can improve economic growth by carrying out business development activities. Often an important measure of social welfare is economic growth.

Free trade could lead to a decline in the exchange rate, decreasing aggregate supply of inputs by-the price of imputed inputs used in manufacturing. (Adhikary, 2011). This leads to a decline in domestic production and to less competitive domestic business. Although the information, technologies and allocation of resources can easily be transferred through open trade, there are many studies which show that the connection between trade transparency and economic growth is negative. The connection between transparency and economic development in the last few decades has been increasingly interested in literature. The global trade mechanism is transparent and competitive over these years. Trade transparency can play an important role in an economy as the productivity and competitive advantage of allocating outlets facilitates know-how and stimulates competitiveness in domestic and foreign markets (Chang, Kaltani \& Loayza, 2009). Most published studies in recent literature indicate that trade openness is an important explicative variable for economic development. This shifts in Malaysia's openness and domestic economic system make it a suitable case study of the time series to investigate the openness of trade openness and economic growth in Malaysia.

Income inequality and the role it plays in economic development have lately gained a great deal of coverage. The IMF weighed in with a debate on the role of income allocation as the source of economic development and its effect (Ostry et al. 2014). There are three different direction of the relationship which is negative, positive and non-linear (Charles-Coll, 2013; Amri, 2017). Binatli (2012) concluded that the detrimental and negligible relation with economic growth is wealth disparities. Further research results have concluded the low growth rates are related to income inequalities (Pede et al. 2009; Davis, 2007; Castello-Climent, 2010). While several studies have attempted to analyze the link between income inequality and economic growth, there is no consensus on the relationship between income inequality and economic growth. Hence, this paper addresses the nature of a long-term association in Malaysia between income inequality and economic development.

One of the biggest threats to developing nations is environmental pollution. All research agrees that the association between economic development and environmental degradation is significant. The positive ties between $\mathrm{CO} 2$ emissions and economic growth have been identified by Ang (2008) and Du, Wei and Cai (2012). Industrialization's economic growth boosted carbon dioxide emissions, which has a detrimental effect on emissions of CO2 (Ejuvbekpokpo, 2014). The relationship between CO2 emissions and economic growth has been zero for Alshehry and Belloumi (2015); Arvin, Pradhan and Norman (2014), Devirens and Deviren (2016); the shift in emissions of carbon dioxide will not shift economic growth. The relationship between depletion of the environment and economic development was thus a critical issue to consider whether or not the amount of $\mathrm{CO} 2$ pollution had an impact on economic 
growth. Since we need sustainable economic growth and prosperity, not at the detriment of future generation and without destruction of the environment, it is necessary, however, to preserve environmental adequacy. Hence, this research is done in order to examine the relationship between environmental degradation and economic growth in Malaysia.

On this note, the emphasis on Malaysia is particularly important. The reason why Malaysia is chosen as a study of my research is because Malaysia has, for over 40 years, been described as one of the "Economic Wonders" of East Asia (UNDP). Malaysia's economic success is significantly related to a more market-focused industrialization strategy, particularly an open-trade policy commitment. The growth plan of Malaysia is a very different path to that pursued by a variety of other developing markets, including those where more recent trade liberalization has shown that income disparity is growing together with the degrading of the environment. Since the aim of becoming an industrial country, as well as the associated rapid economic expansion, there has been a surge in industrial pollution and the deterioration of urbanized areas.

Trade openness, which tends to expand economic growth, has also dramatically increased emissions of air and water. Foreign trade is also an important factor in erosion and depletion of land. Business prosperity has impacted environmental and quality of life expectations. With its new focus on sustainable growth, the impact on the climate of trade openness, both the government of Malaysia and producers, is increasingly daunting. Also, when nations expand trade, the population of the country is positive and poor, and the wage difference or greater income inequality of this country is growing on one hand. The wage difference between eligible and unqualified employees also increases, contributing to inequalities in wealth. Distribution of income concerns to the accumulation of carbon dioxide emissions and thus global warming. Greater wealth inequality is correlated with lower emissions of $\mathrm{CO} 2$ at given average incomes both across and within countries. In some theories it has been said that, economic growth results in higher emissions. Hence, this paper investigates the causal relationship between trade openness, income inequality, environmental degradation and economic growth in Malaysia.

Based on the various researches done, there are different results for these researches done due to the difference in the results of these studies lie with different methodologies used, different study periods explored and country specifics but there is a conclusive evidence about the relationship between these variables and economic growth in Malaysia. Choi, Cho and Heshmati (2010) found that according to the theory of the $\mathrm{EKC}, \mathrm{CO} 2$ emissions ought to be positive and then be negative above the threshold with the amount of income or trade openness. With the negative association between trade openness and $\mathrm{CO} 2$ emissions, the carbon emissions will likely reduce as the country is more open to trade openness. Instead the country would likely lower its level of transparency in free trade if the relation between $\mathrm{CO} 2$ emissions and free trade is positive. In the relation of GDP per capita and environmental degradation there is an inverted $\mathrm{U}$ in the EKC. However, this research is done to determine the whether these three variables have an influence be it positive or negative impact on the economic growth in Malaysia from year 1990 to 2019.

\section{PAST STUDIES}

This paper summarizes the theoretical component of three classes: mercantilism, the classical economist and trade theories. In the one hand, marketing implies that economic competition is a zero-sum system in which economic advantages in one nation were at the expense of another. Exports should be higher than imports. In order to ensure the country becomes prosperous and strong, the national sector should be shielded from import competition (Olasode et al., 2015; Nduka et al., 2013). In the other hand, the classical economist suggests that a country cannot continue to sustain a continuously optimistic trade balance. They assumed that countries would produce and sell goods with a lower cost profit and that the same country could import a product where its absolute cost disadvantage is higher. The point is that international trade engagement may be highly advantageous to economic growth (Keho, 2017; Olasode et al., 2015; Nduka et al., 2013). Many researches are performed in relation to trade, economic development and trade openness have been seen to have a positive effect on economic growth which are Keho (2017), Das and Paul (2011), Marelli and Signorelli (2011), Nowbutsing (2014) and Zarra-Nezhad et al. (2016). Das and Paolo (2011) find the use of a widespread methods of moments of dynamical panel data is that it has a positive influence on economic growth in Asia over the 1971-2009 timeframe. Based on studies reviewed of other countries, the ARDL Boundary Test for Co-integration and the Toda and Yamamoto Granger causality tests were used for the beneficial impact of trade disclosure on economic development in the Côte d'Ivoire in 1965 and 2014. (Keho, 2017). A research by Yeboah et al. (2012) in Africa showed that trade openness has a strong relation to the GDP from 1980 to 2008 in 38 countries. Nduka (2013) still found that opening up trade has a major economic effect Nigeria's economic growth.

Inequality of income refers to income disparity, which is the difference between less fortunate and the more fortunate groups in the world (Shin, 2012). Economic analysis has for a long time been attentive in the relationship between wealth distribution and economic development. Many economic theory studies deal with the correlation between the two variables. However, the essence of the arrangement has not been agreed up to now. In other words, it is still contentious and subject to debate the shape of the relationship between economic development and income inequality (Gallo \& Sagales, 2013). In the early stages of economic growth, wage inequality increases and slides in the later stage of progress according to Kuznets (1955). Kuznets confirmed the theory of an inverted U-shaped curve by relating the per capita gross domestic product to the degree of income distribution inequality. 
In recent years, the theoretical and methodological literature has developed to check the relationship between economic growth and $\mathrm{CO} 2$ emissions in order to examine the determinants of pollution and design strategies for reduction (Pao and Tsai, 2011). In this extensive literature, three research lines have been established which study the relationship between these variables. The first verifies the validity of the EKC and the second explores the links between energy consumption and product (Ozcan, 2013; Ozturk \& Acaravci, 2010;). Due to a benefit threshold, sustainable productivity and a greater emphasis on the sustainability of the environment contribute to manufacturing being environmentally safe, which decreases cumulative pollution.

The relationship between carbon dioxide emissions, income and trade openness depends on the current role of an economy in its growth, because countries have varying income levels and foreign trade dependent auf their level of economic development (Baek et al., 2009). External trade is normal in the early phases of economic progression to add to the rise in wages and use of electricity, in which case the liberalization of trade could lead to faster growth in pollutionintensive manufacturing and levels of emissions in these nations. Studies promoting trade openness on the linkage on the environmental effects include: (Gu, Gao, \& Li, 2013; Ibrahim \& Rizvi, 2015; Sulaiman \& Abdul-Rahim, 2017). However, added research such as Akin (2014), trade openness can reduce $\mathrm{CO}_{2}$ emissions and that the relationship between these two variables are unidirectional. While these findings have definitely enhanced our understanding of the environmental implications of global and international trade, a slight attention has been paid on the causal association between external trade, income growth and environmental quality.

More precisely, these studies deem exogenous environmental quality/damage determinants of international trade and income. This implies a one-way causative relation, such that a shift in trade and income levels results in a consequent shift in the nature of the environment, but not the opposite. The hypothesis neglects the potential endogenous nature of international trade and income, since it has a shared impact on the quality and income of the setting. Chebbi, Olarreaga and Zitouna (2010) have established a significant time between trade openness, income per capita and carbon (CO2) emissions in Tunisia using Johansen and Juselius's cointegration measure. The researcher has also observed a direct influence on $\mathrm{CO} 2$ emissions, both positively and in both the short and long term, although in the long term the indirect effect is negative at least. There are previous researches indicating the increased economic growth plays a significant strain on the environmental quality (Apergis and Payne, 2010b; Arour et al., 2012; Shahbaz et al., 2013b; Tiwari et al., 2013; Omri et al., 2014). As frequently stated in the EKC literature, as the output increases, so does the $\mathrm{CO}_{2}$ until a certain threshold level is achieved, as which the $\mathrm{CO}_{2}$ emissions begin to fall. According to a study done by Kohler (2013), it is typical for foreign trade to contribute to an increased level of income and energy in the early stages of a country's economic growth nevertheless, trade liberalization may lead to a more rapid expansion of emission levels.

\section{CONCEPTUAL FRAMEWORK}

This study aims to investigate the four-way linkages of trade openness, income inequality, environmental degradation and economic growth in Malaysia. In order to accomplish the objectives of this study, there are several techniques that are used with the intention to obtain the results desired in turn of achieving the three objectives in this study. The dependent variable used is gross domestic product (GDP) as an assessment to the economic growth in Malaysia and the independent variables used are trade openness, income inequality and environmental degradation. With the intention to examine the relationship between the dependent variable and independent variables, multiple regression model will be utilized. The functional form is structured as follows:

\section{GDP per capita growth $=\mathrm{f}$ (trade openness, income inequality, environmental degradation)}

According to theory, the expected results are greater energy usage most likely would contribute to greater economic activity and the stimulation of $\mathrm{CO}_{2}$ emissions. The EKC hypothesis notes that the rising energy use which increases the $\mathrm{CO} 2$ emissions is predicted to be positive whereas the income distribution is predicted to be negative. Depending on a country's level of income and economic growth the trade openness is supposed to be either positive or negative. As Malaysia is a developing nation, the expectation is positive since the country fewer state-of-the-art manufacturing technology, and hence factories that aren't the cleanest with a high percentage of pollutants and emissions. This means that a rise in the pollution levels and $\mathrm{CO}_{2}$ emissions which is caused by the comparative advantage in a dirtier production under weaker environmental guidelines would most likely cause an increase in trade openness. (Jayanthakumaran et al. 2012).

\section{DATA AND METHOD}

The variables used in this study are GDP, trade openness (TO), income inequality (GINI) and environmental degradation $\left(\mathrm{CO}_{2}\right)$. The sources of data gained is from World Bank, Department of Statistics and The Global Economy. Since there are three objectives to be examined in this study, hence there would be three equations for this study as well. The variables are then transformed into logarithmic form (log-log model) because it has the lowest coefficient of variation which means it is the most preferred functional model. This step is done in order to ensure that the skewness of the data is decreased and the results are more interpretable. The new models in order to examine the three objectives in this study are as follows:

$$
\begin{aligned}
& \operatorname{LNGDP}_{t}=\beta_{0}+\beta_{1} \text { LNTO }_{t}+\varepsilon_{t} \\
& \operatorname{LNGDP}_{t}=\beta_{0}+\beta_{1} \text { LNTO }_{t}+\beta_{2} \text { LNGINI }_{t}+\varepsilon_{t} \\
& \operatorname{LNGDP}_{t}=\beta_{0}+\beta_{1} \text { LNTO }_{t}+\beta_{2} \text { LNGINI }_{t}+\beta_{3} \text { LNCO2 }_{t}+ \\
& \varepsilon_{t}
\end{aligned}
$$


Where LGDP represents the natural log of Gross domestic product (GDP) per capita, LNTO is the natural log of trade openness, LNGINI represents the natural log of income inequality and $\mathrm{LNCO} 2$ represents the natural $\log$ of environmental degradation.

Different kinds of statistical analysis and test would be conducted in order to examine the relationship between the dependent variable and independent variables. Time series analysis, Ordinary Least Squares (OLS) method, Unit Root tests, The Johansen and Juselius (JJ) Cointegration test, Vector Error Correction Model (VECM) and Granger Causality test. Also, diagnostic tests which consists of Normality test, Serial Correlation LM test, heteroscedasticity test, Ramsey RESET test and CUSUM and CUSUM Squares test. All these tests mentioned would facilitate a deeper level or understanding the study and the objectives, mainly. These tests would be used to test the three different objectives in order to examine the significance of this variables. The period of data being used to run these tests stated is 30 years ranging from 1990 to 2019 . In order to derive valid findings and more characteristics of the results, time series analysis incorporates techniques for analyzing time series data. Time series data has a natural time order. In general, a time series model illustrates the fact that observations close together more closely associated compared to observations further apart. This methodology is used for this study because the data used for this study only consists from one country, Malaysia with a data period of 30 years selected as the sample of this study. Also, Ordinary least squares (OLS) regression is a statistical approach that is able to estimate or forecast the linkages between one or more independent variables and a dependent variable.

Augmented Dickey-Fuller (ADF) test is an enhanced version of the simple Dickey - Fuller test used in the larger time series test. It is useful to correct the higher - order correlation by tallying the lagged dependent differentiation to the right side of the test (Leybourne \& Newbold, 2000). The null hypothesis of $\beta=1$ is order 1 , I (1), which indicates that the series is not stationary, in other words the series has unit root. The alternative hypothesis, $\beta<1$ is 0 , I ( 0$)$ which signifies that in the test, t-statistics was employed to analyze the association between dependent variable and independent variables, implying that the equation lacks a unit root and it considered to be stationary. The variables are evaluated at a $5 \%$ significance level. Null hypothesis will be rejected if $\mathrm{t}-$ statistics are greater than critical value, which, according to rejection criterion, is at the 5\% significance. As a result, the variables are said to be significant since it is stationary and has no unit root (Dickey, 1981). The equation for the ADF test is as follows:

$$
\Delta y=\beta 1+\beta 2+\delta y+a+\sum \Delta Y t-1+\varepsilon t
$$

where $y$ refers to variables of interest, $\Delta$ refers to the operator of differentiation, $t$ refers to the period and $\varepsilon t$ refers to the term of error.

PP test is the modified ADF test version where it is used in the error term to identify possible serial correlation (Philips \& Perron, 1988). In addition, this test also examines the presence in the series of unit roots for each variable. The null hypothesis, $\beta=0$ expresses that the series has unit root and is non - stationary. The alternative hypothesis, on the other hand, $\beta<0$ indicates that the series is stationary without unit root. The equation of PP test is as follows:

$$
\chi_{\mathrm{t}}=\mu+\beta \mathrm{x}_{t-1}+\mu
$$

Where $t=1,2, . \mathrm{T}, \mathrm{x}_{\mathrm{t}}$ denotes times series, and $\mu t$ is the innovation term.

The JJ cointegration test examines the long - run correlation between the dependent and explanatory variables after the first order variables are identified as stationary in the previous test. Through trace statistics and maximum eigen statistics, the number of cointegrating vectors is discovered. The equation of trace test is as follows:

$$
\lambda_{t r}=-T \sum_{i=q+1}^{p} \operatorname{Iog}(1-\lambda \mathrm{i})
$$

where $\mathrm{T}$ denotes the number of observations, $\mathrm{p}$ is the number of variables, whereas $\lambda \mathrm{i}$ is the greatest estimated value of its own. The null hypothesis, $\mathrm{r}=0$ indicates that there is no vector that it is cointegrated. Meanwhile, the alternative hypothesis, $r$ illustrates that the series contains at least one cointegrating vector. According to the rejection rule, for the trace test, if the critical value at $5 \%$ level of significance is lower than the value of the trace test, then the conclusion would be to reject null hypothesis. On the other hand, if the critical value at 5\% significance level is greater than the trace test value, then the conclusion would be to accept the null hypothesis which would mean that the series does not have cointegrating vectors. The Maximum Eigenvalue test is executed for the same purpose as the Trace test. The Maximum Eigenvalue Test equation is stated below:

$$
\lambda_{\max }=-T\left(1-\lambda_{r-1}\right)
$$

where T symbolizes the number of observations for estimated use and $\lambda_{\mathrm{r}-1}$ is the largest estimated value at $\mathrm{r}-1$. The null hypothesis, $r$ vector cointegrating, means there is no vector cointegrating. The alternative hypothesis, $r+1$ cointegrating vector, instead, shows that the series has at least a cointegrating vector. The null hypothesis is said to be rejected in accordance with the rejection rule if the maximum Eigenvalue statistics exceed the critical value at a meaning level of 5 percent. It can therefore be concluded that there is at least one vector that cointegrates. Whereas, the null hypothesis would be to not reject if the statistics of Maximum Eigenvalue are lower than its critical value at a significance level of 5 percent. This means that the series does not have a cointegrating vector.

VECM is a restrictive model of Vector Autoregressive (VAR), which in the long run limits the behaviour of endogenous variables. It thus allows the variables to converge into the relationship of long - term equilibrium and allows long - term dynamics. Based on Granger (1988), Granger Causality testing must be performed in VECM whenever the model of Vector Autoregressive (VAR) is performed to determine the short - term causal 
relationship. VECM is a special case of VAR as it distinguishes between short- and long - term causality of grangers. Relevant terms for error correction (ECT's) must be included in VAR in order to avoid issues such as error specification and omission. By taking the significant restrictions that were excluded in VAR, this ECT prevents mis - specification. Engle \& Granger, (1987) indicate that VECM can distinguish exogenous and endogenous variables to improve the validity of long - term forecasting over a model that is unconstrained. In addition to identifying the path of causality, VECM also detects the root of causation that cannot be identified by tradition al Granger Causality tests.

As mentioned above, this test will be performed if $\mathrm{JJ}$ Cointegration test is found, Conversely, VAR model will be performed to determine the causal short - term relationship if no cointegration is found. This test is a corresponding representation of error - correction. It depicts in detail that variations of the dependent variable can be expressed in the relationship of cointegration and fluctuations in other explanatory variables as a function of disequilibrium (Granger, 1998). The null hypothesis, $\mathrm{H}_{0}$ will be rejected if the calculated value at a meaning level of $5 \%$ is greater than its critical value. It therefore portrays that the selected independent variable does not cause dependent variable to granger. Conversely, the null hypothesis, $\mathrm{H}_{1}$ is accepted if the commuted value at $5 \%$ meaning level is less than the critical value. It deduces that the selected independent variable does not cause dependent variable.

The running of numerous diagnostic tests is a critical stage in time series analysis. There are several diagnostic tests in the literature that are meant to analyze the dependency structure of a time series model. The diagnostic tests used in this study are Normality Test, Serial Correlation LM Test, Heteroskedasticity Test, Ramsey RESET test, CUSUM and CUSUM of Squares Test. Jarque-Bera (JB) Test is used to assess if the study sample has reached the normal distribution of the suit (Gujarati \& Porter, 2009). Normality test used in this research is a very common approach when evaluating the statistical procedures in the linear regression model (Thadewald \& Buning, 2007). Essentially, to test for normal distribution can be checked through two different approaches, which are the formulation based on Jarque-Bera and the method which is based on the $\mathrm{p}$ value. That correlation among the representatives of the sequence of measurements ordered in the time series analysis can be represented as an auto correlation term (Gujarati, 2008). Serial correlation describes whether each observation whether they are related to one another or not. For instance, things happen today, are they going to affect things happen tomorrow? The price of the stock market, commodities and others. If the serial correlation is equals to 0 , then each observation is independent from one another. If not, it will exhibit serial correlation problem. Autoregressive Conditional Heteroscedasticity (ARCH) is a time series statistical technique used to assess the influence of the unexplained, which refers to the error component in an empirical analysis. It represents the variance of the current error term as a function of the true magnitude of the error term for the preceding time period. Ramsay Regression Equation Specification Error Test (Ramsay RESET Test) is the test whether if the model is correctly specified. Whether the model, the independent has the power to explain the dependent variable in the model. Brown, Durbin, and Evans (1975) devised the CUSUM test, which is dependent on the cumulative sum of the recursive residuals. Total Sum of Recursive Residuals and Cumulative Sum of Squared of Recursive Residuals plotted on the diagram with the $5 \%$ centrality dimension of basic lines. On the off chance that all the combined whole lies between the two $5 \%$ hugeness dimension of primary lines, implies that the lingering fluctuation is steady in this relapse model.

\section{RESULTS}

The results of discussion and the significance of these variables are discussed in this chapter. The empirical results obtained are from EViews software in order to check the significance of the dependent and independent variables. The tests used in this study are the Unit Root tests that consists of Augmented Dickey Fuller test and the Phillips Perron test, Johansen \& Juselius Cointegration test which consists of the Trace test and Maximum-Eigenvalue test and the Vector Error Correction Model (VECM) Granger Causality Test and diagnostic tests which consists of Normality test, Serial Correlation LM test, Heteroskedasticity test, Ramsey RESET test, CUSUM and CUSUM of Squares test.

Table 1 shows the result of ADF and PP test of the four variables of this study. The t-statistics of GDP, trade openness and income inequality under both tests are more than critical values of 5\% of significance level at intercept of the level form. On the other hand, environmental degradation under both tests is less than critical value of $5 \%$ of significance level at level and intercept. Therefore, GDP, trade openness and income inequality are not stationary at level form under ADF and PP except environmental degradation, which is stationary at intercept at level under both the tests, ADF and PP. Thus, the first differences are proceeded to identify whether the variables are stationary or not. The t-statistic values of GDP, trade openness and income inequality under both tests are significant at $5 \%$ at first difference and intercept. Hence, it can be concluded that all the variables are stationary at first difference. In short, all variables are stationary at order (1) in the first difference form. So, all the variables were significant at the same order which is at first difference and intercept hence, it can be said that these variables are stationary, no unit root and mean reverting. These findings allow the proceeding of the Johansen Cointegration analysis since all the variables had the same order of cointegration. 
Table 1. Augmented Dickey Fuller (ADF) \& Phillips Perron (PP) Test Results

\begin{tabular}{|c|c|c|c|c|}
\hline & \multicolumn{2}{|c|}{$\begin{array}{l}\text { Augmented Dickey-Fuller Test } \\
\text { (ADF) }\end{array}$} & \multicolumn{2}{|c|}{ Phillips - Perron Test (PP) } \\
\hline & t-statistics & Prob. & t-statistics & Prob. \\
\hline \multicolumn{5}{|c|}{ A: Level \& Intercept } \\
\hline GDP & $-2.698(0)$ & $0.0865(0)$ & $-2.516(3)$ & $0.1223(3)$ \\
\hline TO & $-0.1479(0)$ & $0.9346(0)$ & $-0.4084(2)$ & $0.8950(2)$ \\
\hline GINI & $-0.5764(4)$ & $0.9357(4)$ & $-0.7565(0)$ & $0.8153(2)$ \\
\hline $\mathrm{CO}_{2}$ & $-3.258(0)$ & $0.0266(0) *$ & $-3.321(2)$ & $0.0231(2) *$ \\
\hline \multicolumn{5}{|c|}{ B: First Differences \& Intercept } \\
\hline GDP & $-7.072(1)$ & $0.0000(1) *$ & $-20.81(27)$ & $0.0001(27) *$ \\
\hline TO & $-3.970(0)$ & $0.0051(0) *$ & $-4.013(6)$ & $0.0046(6) *$ \\
\hline GINI & $-5.930(3)$ & $0.0001(3) *$ & $-3.292(9)$ & $0.0258(9) *$ \\
\hline $\mathrm{CO}_{2}$ & $-5.227(0)$ & $0.0002(0) *$ & $-5.232(1)$ & $0.0002(1) *$ \\
\hline
\end{tabular}

Note: Asterisks (*) indicate statistically significant at 5\% level. Parentheses are lag lengths. GDP = Gross Domestic Product, $\mathrm{TO}=$ Trade Openness, GINI $=$ Income Inequality, $\mathrm{CO}_{2}=$ Carbon Dioxide Emissions

Table 2. Johansen \& Juselius (JJ) Cointegration Test Results

\begin{tabular}{llllll}
\hline $\mathbf{k}=\mathbf{1} \mathbf{r}=\mathbf{1}$ & \multicolumn{3}{c}{ Trace } & \multicolumn{3}{c}{ Max - Eigen } \\
\hline Null & Alternative & Unadjusted & $\mathbf{9 5 \%} \mathbf{C .} \mathbf{V}$ & Unadjusted & $\mathbf{9 5 \%} \mathbf{C .} \mathbf{~ V}$ \\
\hline $\mathbf{r}=\mathbf{0}$ & $\mathbf{r}=\mathbf{1}$ & $98.34^{*}$ & $47.86^{*}$ & $62.81^{*}$ & $27.58^{*}$ \\
$\mathbf{r} \leq \mathbf{1}$ & $\mathbf{r}=\mathbf{2}$ & $35.53^{*}$ & $29.80^{*}$ & $23.87^{*}$ & $21.13^{*}$ \\
$\mathbf{r} \leq \mathbf{2}$ & $\mathbf{r}=\mathbf{3}$ & 11.66 & 15.49 & 10.58 & 14.26 \\
$\mathbf{r} \leq \mathbf{3}$ & $\mathbf{r}=\mathbf{4}$ & 1.077 & 3.841 & 1.077 & 3.841
\end{tabular}

Note: Trace test and Max-Eigen test indicates 2 cointegrating eqn(s) at the 0.05 level

$*$ denotes rejection of the hypothesis at the 0.05 level

According to both the tests results, it is illustrated in table 2 that long run relationship exists between these four variables. This test is mainly used to test the long run equilibrium between the variables. The null hypothesis of no cointegrating vector $(\mathrm{r}=0)$ in favor of at least one cointegrating vector is rejected at 5\% significance level for both Trace test and Max test. The null hypothesis $(\mathrm{r} \leq 1)$ is similarly rejected at $5 \%$ significance level for both the tests performed. This demonstrates that that the Trace and Max test revealed two cointegrating vectors at the $5 \%$ significance level. For the Trace and Max tests, a significance level of less than 0.05 indicates the rejection of the null hypothesis of $r=0$. As a result, rejecting the null hypothesis of no cointegration $(\mathrm{r}=0)$ implies that there are four variables that do not drift apart and have at least two common stochastic trends in the long run.
Both these tests show that there are two distinct cointegrating relationships between the four variables, indicating that there are two long run relationships found within these four variables. In a nutshell, there are two cointegrating vectors found which shows that the chosen macroeconomic variables have a long-term implication on economic growth. So, Vector Error Correction Model (VECM) Granger causality framework is for the subsequent causality test as long run relationship between the variables does exists in the model. 
Table 3: Normalized Equation Estimation Results

\begin{tabular}{|c|c|c|}
\hline Variables & Coefficient & T-statistics \\
\hline LGDP & - & - \\
\hline LTO & 1.8728 & $14.8838 *$ \\
\hline LGINI & -5.6752 & $-12.2323^{*}$ \\
\hline $\mathrm{LCO}_{2}$ & 0.8452 & $7.55756^{*}$ \\
\hline
\end{tabular}

Note: Asterisks (*) indicate statistically significant at 5\% level. Parentheses are lag lengths. GDP $=$ Gross Domestic Product, $\mathrm{TO}=$ Trade Openness, GINI = Income Inequality, $\mathrm{CO} 2$ = Carbon Dioxide Emissions

The normalized equation is as follow:

$$
\begin{gathered}
\mathrm{LNGDP}=17.34+1.8728 \mathrm{LNTO}-5.6752 \mathrm{LNGINI}+ \\
0.8452 \mathrm{LNCO}_{2} \quad \ldots \text { Eq. }(8)
\end{gathered}
$$

Based on the table 3 above, it is shown that the variable LTO has a significant positive effect towards LGDP which means that $1 \%$ inclination in LTO will result in $1.87 \%$ increase in LGDP while holding LGINI and $\mathrm{LCO}_{2}$ constant at $5 \%$ significance level. Whereas, LGINI has a significant negative impact towards LGDP since a $1 \%$ increase of LGINI would in turn decrease LGDP by $5.68 \%$ while holding LTO and $\mathrm{LCO}_{2}$ constant at 5\% significance level. Variable $\mathrm{LCO}_{2}$ has a positive impact towards LGDP as well. This means that an increase in $1 \%$ in $\mathrm{LCO}_{2}$ would result in an increase of $0.84 \%$ in LGDP while holding LTO and LGINI constant at 5\% significance level.

Table 4 shows the Granger causality results of every selected variable. The $\chi^{2}$ statistics captures the short run behavior of these variables. Meanwhile, the error correction term (ECT) seizes the long run behavior between these variables. The results above terms that short run relationship are distinguished between these variables. Furthermore, there is long run adjustment in these 4 model variables with two ECT correspondingly.

There are seven short run relationships present in the case of this four-variable model. First, a unidirectional short-run causality is identified running from LTO to LGDP as its probability value is 0.0038 which is lesser than $5 \%$ significance level which is 0.005 . Thus, the null hypothesis of LTO does not granger cause LGDP is rejected at 5\% significance level since LTO does granger cause LGDP. There is a unidirectional causality running from LGINI to LGDP since the probability value is lesser than $5 \%$ significance level, hence the null hypothesis is rejected. There is a bidirectional causality between variables $\mathrm{LCO}_{2}$ an LGDP which means $\mathrm{LCO}_{2}$ does granger cause LGDP as well as LGDP does granger cause $\mathrm{LCO}_{2}$ since the probability is lesser than $5 \%$ significance level, hence null hypothesis is rejected. There also seems to be a short run causality that runs from LTO to LGINI with the probability valued at 0.0102 which is lesser than 5\% significance level which means that LTO does granger cause LGINI. There is a unidirectional causality running from LTO to $\mathrm{LCO}_{2}$ which means LTO does granger cause $\mathrm{LCO}_{2}$. Lastly, LGINI does granger cause $\mathrm{LCO}_{2}$ which means null hypothesis is rejected because the probability value is lesser than 5\% significance level.

The ECT on the other hand must compulsorily fulfill three rules of thumb, where the coefficient must be negative, less than one and the variable must be significant at 5\% level of significance. The ECT measures the speed of adjustment towards long run equilibrium if any deviation is present. Looking at the four-variable model, it can be seen that variables LTO and $\mathrm{LCO}_{2}$ fulfill the entire rules where the coefficient is -0.299 with $29.9 \%$ and -0.574 with $57.4 \%$ of adjustment happen in a year respectively. So, variable LTO needs 3.3 years and variable $\mathrm{LCO}_{2}$ needs 1.7 years adjusting itself to the long run equilibrium if disequilibrium ensues respectively.

\begin{tabular}{|c|c|c|c|c|c|c|}
\hline \multirow{2}{*}{$\begin{array}{c}\text { Dependent } \\
\text { Variable }\end{array}$} & $\Delta$ LGDP & $\triangle L T O$ & $\Delta L G I N I$ & $\triangle L C O_{2}$ & \multirow[b]{2}{*}{ Coefficient } & \multirow[b]{2}{*}{ t-ratio } \\
\hline & \multicolumn{4}{|c|}{$\begin{array}{c}X^{2} \\
\text { Statistics } \\
\text { (p-value) }\end{array}$} & & \\
\hline$\Delta$ LGDP & - & $\begin{array}{c}11.15 \\
(0.0038) *\end{array}$ & $\begin{array}{c}41.98 \\
(0.0000) *\end{array}$ & $\begin{array}{c}18.02 \\
(0.0001) *\end{array}$ & -2.360 & {$[-4.978]$} \\
\hline$\triangle L T O$ & $\begin{array}{c}2.155 \\
(0.3404)\end{array}$ & - & $\begin{array}{c}1.696 \\
(0.4283)\end{array}$ & $\begin{array}{c}0.151 \\
(0.9271\end{array}$ & -0.299 & {$[-1.994] *$} \\
\hline$\Delta L G I N I$ & $\begin{array}{c}1.942 \\
(0.3787)\end{array}$ & $\begin{array}{c}9.165 \\
(0.0102) *\end{array}$ & - & $\begin{array}{c}2.375 \\
(0.3050)\end{array}$ & -0.043 & {$[-1.244]$} \\
\hline$\triangle \mathrm{LCO}_{2}$ & $\begin{array}{c}6.788 \\
(0.0336) *\end{array}$ & $\begin{array}{c}8.683 \\
(0.0130) *\end{array}$ & $\begin{array}{c}12.48 \\
(0.0019) *\end{array}$ & - & -0.574 & {$[-2.657] *$} \\
\hline
\end{tabular}

Table 4: VECM Granger Causality Test Results

Note: Asterisks (*) indicate statistically significant at 5\% level. Parentheses are lag lengths. GDP = Gross Domestic Product, TO $=$ Trade Openness, GINI $=$ Income Inequality, $\mathrm{CO} 2=$ Carbon Dioxide Emissions 


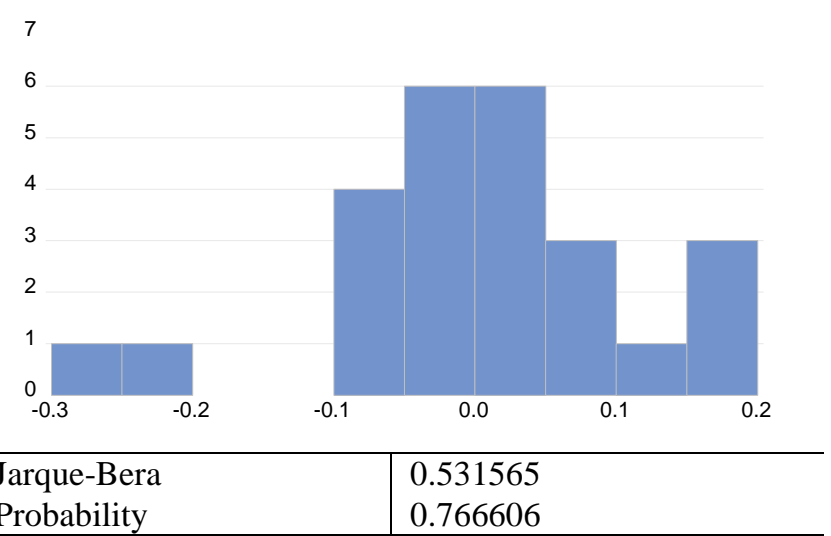

Figure 1: Results of Jarque-Bera test

Since the p-value is equivalent to 0.7667 which is more than the $5 \%(0.05)$ of significance level. Hence, do not reject $\mathrm{HO}$ so the error term is normally distributed.

Table 5: Results of Breusch-Godfrey Serial Correlation LM Test

\begin{tabular}{l|l|l|l}
\hline F-statistics & 0.6101 & $\begin{array}{l}\text { Prob.F } \\
\text { Prob. Chi- }\end{array}$ & 0.5581 \\
$\begin{array}{l}\text { Obs*R- } \\
\text { Squared }\end{array}$ & 2.145 & \begin{tabular}{l} 
Square \\
\hline
\end{tabular} & \\
\hline
\end{tabular}

The probability of Chi-Square is 0.3421 which is more $0.05,5 \%$ significance level. This means that $\mathrm{H}_{0}$ is not rejected and it can be concluded that the error term does not exhibit serial correlation problem.

Table 6: Results of Heteroscedasticity ARCH test

\begin{tabular}{l|l|l|l}
\hline F-statistics & 1.534 & Prob.F & 0.2285 \\
Obs*R- & 1.565 & $\begin{array}{l}\text { Prob. Chi- } \\
\text { Square }\end{array}$ & 0.2109 \\
\hline
\end{tabular}

The p-value is 0.2285 which is greater than $5 \%$ significance level (0.05). Thus, the conclusion would be do not reject $\mathrm{H}_{0}$ and since null hypothesis is accepted this means that there is no heteroscedasticity problem.

Table 7: Results of Ramsey RESET test

\begin{tabular}{l|l|l}
\hline & Value & Probability \\
\hline t-statistic & 0.5746 & 0.5747 \\
F-statistic & 0.3302 & 0.5747 \\
Likelihood ratio & 0.5828 & 0.4452 \\
\hline
\end{tabular}

The p-value shown in Table 7 is 0.5747 which is higher than 5\% significance level (0.05). Thus, do not reject
$\mathrm{H}_{0}$ and it can be concluded that the model is correctly specified.
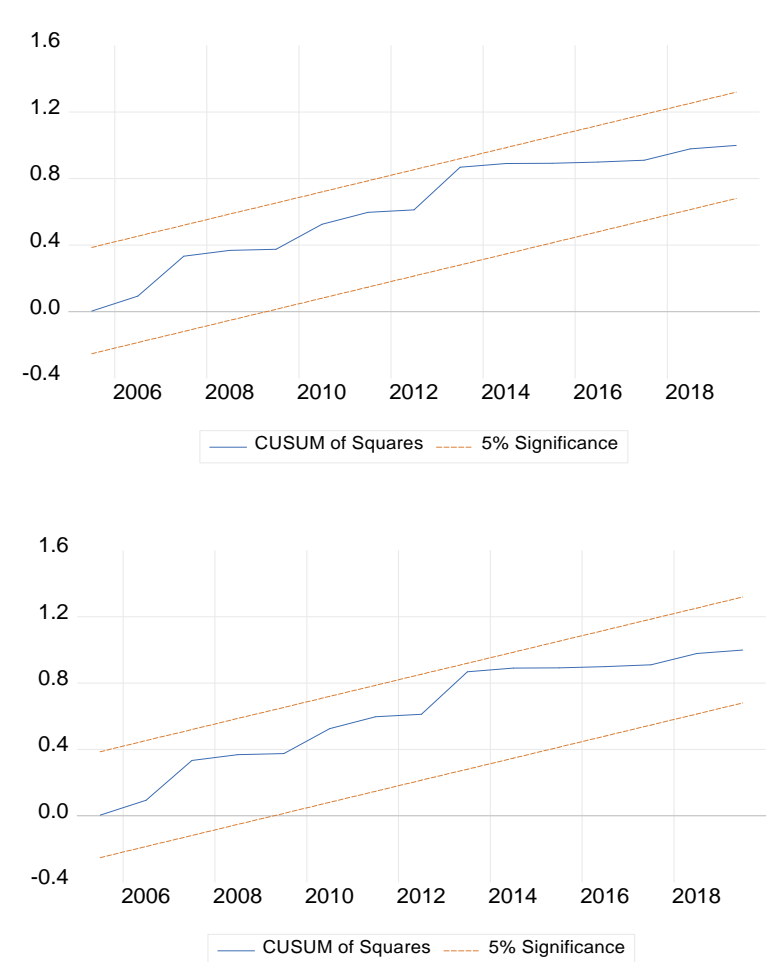

Figure 2: Results of CUSUM and CUSUM of Squares test

The choice guideline is to not dismiss the null hypothesis when the aggregate total is inside a $5 \%$ centrality dimension of basic lines. This implies there is a stable OLS relapse model. So, it can be concluded that the model is stable.

\section{DISCUSSION OF THE RESULTS}

and Strutt (2010). Increased international commerce can spur economic growth by enabling the spread of knowledge and technology. Trade fosters integration and improves profits from foreign direct investment, with the sources of innovation. It also helps economies to obtain opportunities to expand its business.

The results also prove that environmental degradation has a positive impact on economic growth which is in line with the Cederborg et al., (2016) because according to them, As the economy increases, according to the results, $\mathrm{CO} 2$ emissions also increase. The positive association may also be seen at the greatest level of importance for both industrial countries. The results therefore fail to demonstrate the presence, particularly over the long term, of the EKC hypothesis in the Malaysian economy which is consistent with a study of the MENA nations of Arouri et al. (2012), Fodha and Zaghdoud (2010) in Tunisia and Halicioglu (2009) in Turkish economy.

Income inequality on the other hand indicates that it is detrimental as it seriously damages people's incomes and increases poverty. It also limits financial availability and reduces all possible investments and possibilities for 
impoverished people. In a downturn, inequality causes increased crime and violence and the institutional defense of property rights becomes weaker. From the results obtained, as trade openness results in a rise in economic activities and subsequently an increase in income in a nation, the data collected suggest that the relationship between foreign trade and income is indeed linked positively (Kohler, 2013). The findings indicate that rise of GDP and trade openness, supported by Farhani et al. (2013), tends to lead to more CO2 emissions, so it can be said that greater trade openness increases emissions. International trade, according to Fernández-Amador et al. (2016), connects local markets to global ones, propagating the consequences of $\mathrm{CO} 2$ pricing/tax systems across borders. In fact, the import of carbon-intensive inputs can bypass national policy targeting emissions locally. The worldwide demand for goods and services therefore leads to carbon emissions incorporated into these items (FernándezAmador et al., 2016). The rise in $\mathrm{CO} 2$ hence raises the inequality in income which has shown to be negative for Malaysia's economic growth in the long haul. High income inequality, according to Yang et al. (2020), disrupts status consumption.

Even though $\mathrm{CO} 2$ emissions have a positive impact on the economic growth, the income inequality has a negative impact which means there is a need to reduce environmental degradation. According to Eddine Chebbi et al. (2011), policymakers should emphasize that the economically effective solution does not entail reversing trade liberalization, but rather regulatory tools and regulations that assist companies in internalizing the cost of their environmental activities.

\section{CONCLUSION}

From the tests above, it can be proven that there are long and short run relationships between these variables. So, it can be said that the general objective of this study is achieved. The general objective is to investigate the four-way linkages between trade openness, income inequality, environmental degradation and economic growth in Malaysia, which means that from the tests that was carried out the general objective was achieved. These four variables are linked to each other as proven by the tests discussed in this chapter. There is existence of relationship between these variables, trade openness, income inequality, environmental degradation and economic growth in Malaysia which achieves the aim of this study. The pros and cons need to be addressed by the policymakers in order to ensure the continuous and sustainable growth of the economy. Hence, the aim of this as per mentioned in the objectives has been achieved.

\section{REFERENCES}

[1] Alesina, A., Spolaore, E., \& Wacziarg, R. (2000). Economic integration and political disintegration. Am. Econ. Rev, 90 (5), 1276-1296.

[2] Almeida, R., \& Fernandes, A. (2008). Openness and technological innovations in developing countries:evidence from firm- level surveys. J. Dev. Stud, 44(5), 701-727.
[3] Arouri, M.E., Youssef, A., M'henni, H., Rault, C., 2012. Energy consumption, economic growth and $\mathrm{CO}_{2}$ emissions in Middle East and North African countries. Energy Policy 45, 342-349.

[4] Baek, J., Cho, Y. \& Koo, W.W. (2009). The environmental consequences of globalization: A country specific time- series analysis. Ecological Economics, 68, 2255- 2264.

[5] Barro, R.J. \& Sala-i-Martin, X. (1997). Technological diffusion, convergence, and growth. J. Econ. Growth, 2 (1). 2-26

[6] Birdsall, N., \& Wheeler, D. (1993). Trade policy and industrial pollution in Latin America: where are the pollution havens? Journal of Environment and Development 2, 137-149.

[7] Bond, E.W., Jones, R.W., \& Ping, W.(2005). Economic takeoffs in a dynamic process of globalization. Rev. Int. Econ, 13 (1), 1-19.

[8] Brown, R.L., Durbin, J. \& Evans, J. (1975). Techniques for Testing the Constancy of Regression Relationships over Time. Journal of the Statistical Society Series B,37, 149-192.

Royal

[9] Cederborg, J., Snöbohm, S., Mentor, \& Blomskog, S. (2016.). Is there a relationship between economic growth and carbon dioxide emissions. Institution of Social Sciences.

[10] Chang, R., Kaltani L., \& Loayza, N. V. (2009). Openness can be good for growth: The role of policy complementarities. Journal of Development Economics, 90(1), 33-49.

[11] Chebbi, H. E., Olarreaga, M. \& Zitouna, H. (2010). Trade openness and $\mathrm{CO} 2$ emissions in Tunisia.Working Paper 518, Economic Research Forum

[12] Cole, M.A., Elliott, J.R.J., \& Azhar, A.K. (2000). The determinants of trade in pollution intensive industries: North - South evidence, University of Birmingham, UK, Mimeo.

[13] Dean, J. (2002). Does trade liberalization harm the environment? A new test. Canadian Journal of Economics, 35 (4), 819-842.

[14] De Ferranti, D., Ferreira, F. H. G. and Perry, G. E., Walton, M. (2004). Inequality in Latin America: breaking with history? World Bank Latin American and Caribbean Studies. Washington, DC: World Bank.

[15] Department of Statistics Malaysia Official Portal. (2019). Dosm.Gov.My. https://www.dosm.gov.my/v1/

[16] Dollar, D., \& Kraay, A. (2004). Trade. Growth and Poverty. Economic Journal, 114, 22-49.

[17] Dickey, D. A. (1981). Likehood ration statistics for autogressive time series with unit root. Econometrica, $\quad 49,1057$ - 1072

[18] Dinda, S., \& Coondoo, D. (2006). Income and emission: A panel data-based cointegration analysis. Ecological Economics, 57(2): 167-181.

[19] Engle, R. F., \& Granger, C. J. (1987). Cointegration error correction: Representation, estimation and testing. Economterica,55, 257-276.

[20] Eddine Chebbi, H., Olarreaga, M., \& Zitouna, H. (2011). Trade Openness and $\mathrm{CO}_{2} \quad$ Emissions in Tunisia. Middle East Development Journal, 3(1), $29-53$.

[21] Edwards, S. (1998). Openness, productivity and growth: What do we really know? The Economic Journal, 108(447), 383-398. 
[22] Fæhn, T., \& Bruvoll, A. (2009). Richer and cleaner-At others' expense? Resource and Energy Economics,31(2), 103-122.

[23] Farhani, S., Shahbaz, M., \& El, M. (2013). Panel analysis of $\mathrm{CO}_{2}$ emissions, GDP, energy consumption, trade openness and urbanization for MENA countries Munich Personal RePEc Archive. Uni- Muenchen.de.

[24] Fodha, M., \& Zaghdoud, O. (2010). Economic growth and pollutant emissions in Tunisia: An empirical analysis of the environmental Kuznets curve. Energy Policy, 38(2), 1150- 1156.

[25] Frankel, J. A., \& Romer, D. (1999). Does trade cause growth? American Economic Review, 89, 379-399.

[26] Granger, C. W. (1998). Some recents Developments in a Concept of causality. Journal of Econometrics 39, 199- 211.

[27] Grether, J., Mathys, N. A., \& De Melo, J. (2010). Global manufacturing SO2 emissions: Does trade matter? Review of World Economics, 145(4), 713-729.

[28] Gujarati, D. N. (2008). Basic Econometric. New York: McGraw-Hill Irwin.

[29] Gujarati, D. N., \& Porter, D. C. (2009). Basic Econometrics ( $5^{\text {th }}$ ed.). USA: McGraw Hil. Boston, MA: Mc Graw Hill/Irwin.

[30] Halicioglu, F. (2009). An Econometric Study of CO2 Emissions, Energy Consumption, Income and Foreign

Trade in Turkey. Energy Policy, 37,

$1156-$

1164.

[31] Jayanthakumaran, K., Verma, R., \& Liu, Y. (2012). CO2 emissions, energy consumption, trade and income: a comparative analysis of China and India. Energy Policy, 42, 450-460.

[32] Karras, G. (2003). Trade openness and economic growth: Can we estimate the precise effect? Applied Econometrics and International Development,

$3(1), 7-26$.

[33] Keho, Y. (2017). The impact of trade openness on economic growth: The case of Cote d'Ivoire. Cogent Economics and Finance, 5(1), 1-14.

[34] Kohler, M. (2013). $\mathrm{CO}_{2}$ emissions, energy consumption, income and foreign trade: A South African perspective. Energy Policy, 63, 1042-1050.

[35] Lucas, R.E.B., Wheeler, D., Hettige, H. (1992). international migration of toxic industrial pollution: 1960 - 1988, in: Low, P. (Eds.), International Trade and the Environment, World Bank discussion paper 159, 67-87.

[36] Leybourne, S. J., \& Newbold, P. (2000). Behaviour of Dickey fuller t-tests where there is a break under the alternative of a unit root test: How sure are we that economic timeseries have aunit root? Journal of Econometrics, 159-178.

[37] Miller, S., \& Russek, S. (1990). Co-Integration and Error Correction Model: The temporal causality between government taxes and spending. Southern Economic Journal, 57, 221-229.
[38] Muinelo-Gallo, L., \& Roca-Sagalés, O. (2011). Economic growth and inequality: The role of fiscal policies. Australian Economic Papers, 50(2-3), 74-97

[39] Nduka, K.E. (2013). Openness and economic growth in Nigeria. Journal of Education and Practice, 4(1), 68- 73.

[40] Nduka, E.K., Chukwu, J.O., Kalu, I.K., \& Nwakaire, O.N. (2013), Trade openness and economic growth: A comparative analysis of the pre and post structural adjustment programme (Sap) Periods in Nigeria. Asian Journal of Business and Economics, 3(3), 1-12.

[41] Nowbutsing, B.M. (2014). The impact of openness on economic growth: Case of Indian Ocean Rim countries.Journal of Economics and Development Studies, 2(2),407- 427.

[42] Olasode, S.O., Raji, O., Adedoyin, O.A., \& Ademola, I.A. (2015), Trade openness and economic growth a reflection from Nigeria (1981-2 012). International Journal of Economics, Commerce and Management, 3(5), 813-820.

[43] Ozcan, B. (2013). The nexus between carbon emissions, energy consumption and economic growth in middle East countries: a panel data analysis. Energy

Policy, 62, 1138-1147.

[44] Ozturk, I., \& Acaravci, A. (2013). The long run and causal analysis of energy, growth, openness and financial development on carbon emissions in Turkey.

Energy Econ, 36, 262-267.

[45] Panayotou, T. (2003). Economic growth and the environment. Economic survey ofEurope, 45-72.

[46] Peterson, E. W. F. (2017). Is economic inequality really a problem? A review of the arguments. Social Sciences, 6(4), 147.

[47] Philips, P. C., \& Perron, P. (1988). Testing for a unit in time series regression. Biometrica,75, 335-346.

[48] Saboori, B., Sulaiman, J., \& Mohd, S. (2012). Economic growth and $\mathrm{CO}_{2}$ emissions in Malaysia: $\mathrm{A}$ cointegration analysis of the environmental Kuznets curve. Energy Policy, 51, 184-191.

[49] Suri, V., \& Chapman, D. (1998). Economic growth, trade and energy: implications for the environmental Kuznets curve. Ecological Economics 25, 195-208.

[50] Thadewald \& Büning. (2007). Jarque-Bera Test and its Competitors for Testing Normality - A Power Comparison. Journal of Applied Statistics,34(1),87-105.

[51] Yang, B., Ali, M., Hashmi, S. H., \& Shabir, M. (2020). Income Inequality and $\mathrm{CO}_{2}$ Emissions in Developing Countries: The Moderating Role of Financial Instability. Sustainability, 12(17), 6810.

[52] Yeboah, O., Naanwaab, C., Saleem, S., \& Akuffo, A.A. (2012). Effects of Trade Openness on Economic Growth: The Case of African Countries. Birmingham: Agribusiness, Applied Economic and AgroSciences Education. NC A\&T.

[53] Zarra-Nezhad, M., Hosseinpour, F., \& Arman, S.A. (2016) Trade-growth nexus in developing and developed countries: An application of extreme bounds analysis. Asian Economic and Financial Review, 4(7), 915-929. 